\title{
Bonamia exitiosus n.sp. (Haplosporidia) infecting flat oysters Ostrea chilensis in New Zealand
}

\author{
P. M. Hine ${ }^{1, *}$, N. Cochennec-Laureau ${ }^{2}$, F. C. J. Berthe ${ }^{2}$ \\ ${ }^{1}$ National Institute of Water and Atmospheric Research, PO Box 14-901, Kilbirnie, Wellington, New Zealand \\ ${ }^{2}$ IFREMER, Laboratoire de Génétique et Pathologie, BP 133 Ronce-les Bains, La Tremblade 17390, France
}

\begin{abstract}
Bonamia sp. is a pathogenic parasite that occurs in the haemocytes of dredge oysters Ostrea chilensis Philippi in New Zealand. Ultrastructurally it resembles other haplosporidians in the possession of haplosporosomes, haplosporogenesis, persistence of mitotic microtubules during interphase and of the nuclear envelope during mitosis, and occurrence of a diplokaryotic or multi-nucleate plasmodial stage. Another stage containing a large vacuole derived from enlargement of 1 or more mitochondria has not previously been described from other haplosporidians. It most closely resembles $B$. ostreae Pichot et al., 1979, which parasitises and is pathogenic in haemocytes of European flat oysters, $O$. edulis. However, $B$. ostreae is smaller and denser, and has fewer lipoid bodies and haplosporosomes. We have nearly completely sequenced the small ribosomal gene of the organism from $O$. chilensis. Initial comparisons of these sequences with those of other protozoans showed similarities to B. ostreae. Polymorphism within Bonamia sp. was confirmed by restriction fragment length polymorphism analysis. On the basis of ultrastructural and molecular considerations it is proposed that this organism be named Bonamia exitiosus sp. nov.
\end{abstract}

KEY WORDS: Bonamia exitiosus · Ostrea chilensis · Ultrastructure $\cdot$ 18S rDNA · New Zealand

\section{INTRODUCTION}

From late 1985 until 1993, large scale mortalities occurred among oysters (Ostrea [= Tiostrea] chilensis Philippi) in Foveaux Strait, south of the South Island of New Zealand, reducing the population of oysters in 1990 by $67 \%$ and in 1992 by $91 \%$ of the stocks present in 1975 (Doonan et al. 1994). The fishery was closed in 1993, which had a severe economic impact on local communities. Mortalities were associated with an epizootic of a haplosporidian parasite, apparently lacking a spore stage, that occurred in haemocytes. It resembled Bonamia ostreae Pichot et al. 1979 in Ostrea edulis in Europe and was therefore called Bonamia sp. (Dinamani et al. 1987, Hine 1991a,b, 1992, 1996, Hine \& Wesney 1992, 1994a,b, Hine \& Jones 1994). Subse-

${ }^{*}$ Present address: Aquatic Animal Diseases, National Centre for Disease Investigation, MAF Operations, PO Box 40-742, Upper Hutt, New Zealand. E-mail: hinem@maf.govt.nz quent investigations have shown that the parasite was present in Foveaux Strait oysters in 1964, and a longstanding association between host and parasite is suggested by a consistent annual pattern of infection (Hine 1991a,b).

Studies have already been published on the ultrastructure (Hine 1991b, Hine \& Wesney 1992) and functional anatomy (Hine \& Wesney 1994a) of Bonamia sp. In spite of ultrastructural studies on B. ostreae (Comps et al. 1980, Brehélin et al. 1982, Balouet et al. 1983, Grizel 1985, Chagot et al. 1992, Mourton et al. 1992, Montes et al. 1994), it is difficult to identify features that clearly distinguish the 2 species. Some monoclonal antibodies raised against $B$. ostreae labelled Bonamia sp. (Mialhe et al. 1988). A specific B. ostreae DNA probe also led to the labelling of Bonamia sp. (Cochennec et al. 2000). These results confirm the close affinity of the 2 organisms and the need for identification keys for Bonamia spp. This paper presents ultrastructural data and 18S sequence of Bonamia exitiosus sp. nov. 


\section{MATERIALS AND METHODS}

Ultrastructural studies. Infected Ostrea chilensis (n = 237) from Foveaux Strait were opened one at a time, the heart was removed and cut in two, imprints were made with one half, and the other half was fixed for ultrastructural studies. Imprints were stained with Hemacolor $^{\mathrm{TM}}$ (Merck) and microscopically examined, and heavily infected oysters were selected for further study. Hearts were fixed in $2.5 \%$ glutaraldehyde in $0.22 \mu \mathrm{m}$ filtered seawater for 1 to $2 \mathrm{~h}$, washed twice in filtered seawater, post-fixed in $1 \% \mathrm{OsO}_{4}$ for $1 \mathrm{~h}$, stained en bloc with $5 \%$ uranyl acetate in $0.1 \mathrm{M}$ sodium acetate buffer for $45 \mathrm{~min}$, dehydrated in ascending (50 to 100\%) ethyl alcohol, embedded in Araldite, sectioned, stained with $5 \%$ uranyl acetate for $10 \mathrm{~min}$ and in $5 \%$ lead citrate for 5 to 6 min, and examined on a Philips 420ST TEM.

To compare Bonamia sp. with B. ostreae, quantitative data were taken from published studies on the ultrastructure of B. ostreae (Pichot et al. 1979, Comps et al. 1980, Brehélin et al. 1982, Balouet et al. 1983, Grizel et al. 1983, Grizel 1985, Hervio et al. 1991, Chagot et al. 1992) and from archived material held at the IFREMER laboratory at Ronce-les-Bains, La Tremblade, France. Samples were compared directly under the TEM from blocks of $B$. ostreae infected Ostrea edulis kindly lent by Steve Feist of the MAFF Fish Diseases Laboratory, Weymouth, England.

Base sequence studies. DNA extraction: Genomic DNA was extracted from Bonamia sp. infected Ostrea chilensis using the following procedure. Ethanol fixed tissues were suspended in $1 \mathrm{ml}$ of extraction buffer ( $\mathrm{NaCl} 100$ mM, EDTA 25 mM, pH 8, SDS 0.5\%) with proteinase $\mathrm{K}\left(100 \mu \mathrm{g} \mathrm{ml} \mathrm{m}^{-1}\right)$. Following an overnight incubation at $50^{\circ} \mathrm{C}$, DNA was extracted using a standard phenol/chloroform protocol followed by ethanol precipitation (Sambrook et al. 1989).

DNA amplification, cloning and sequencing: The nearly complete small subunit (SSU) rDNA gene was amplified from the Bonamia sp. DNA using universal primers pair SUni-CAS2 (Le Roux et al. 1999). PCR was performed in a $50 \mu \mathrm{l}$ vial containing about $10 \mathrm{ng}$ of DNA mixed with $5 \mu \mathrm{l}$ of $10 \times$ PCR buffer, $5 \mu \mathrm{l}$ of $25 \mathrm{mM}$ $\mathrm{MgCl}_{2}, 5 \mu \mathrm{l}$ of $2 \mathrm{mM}$ deoxyribonucleoside5'-triphosphates, $0.5 \mu \mathrm{l}$ of each $100 \mu \mathrm{M}$ primer and $0.25 \mu l$ (1 unit) of Taq DNA polymerase (Promega). Samples were denatured for $5 \mathrm{~min}$ at $94^{\circ} \mathrm{C}$ and amplified by 30 cycles of $1 \mathrm{~min}$ at $94^{\circ} \mathrm{C}$ for denaturation, $1 \mathrm{~min}$ at $55^{\circ} \mathrm{C}$ for primers annealing and $1 \mathrm{~min}$ at $72^{\circ} \mathrm{C}$ for elongation in a thermal cycle apparatus (Appligene, Illkirch, France). Polymerisation at $72^{\circ} \mathrm{C}$ was then extended for $10 \mathrm{~min}$ to ensure complete elongation of the amplified products. After amplification, $5 \mu \mathrm{l}$ of amplified DNA fragment was analysed by electrophoresis on ethidium bromide staining agarose gels ( $1 \%$ in Tris Acetate EDTA buffer). The amplified fragment was cloned using pCR2.1 Vector System (Invitrogen, Cergy, Pontoise, France). Minipreps of recombinant plasmids were prepared according to standard alkaline lysis protocol with an additional step of phenol/chloroform extraction and ethanol precipitation. Two recombinant plasmids were sequenced using the T7 Sequencing KIT according to the manufacturer's recommendations (Pharmacia Biotech). Termination products were separated by electrophoresis through a $6 \%$ polyacrylamide gel and detected by autoradiography. Sequences were compared for similarity with public databases lodged in GenBank and EMBL using a basic local alignment search tool (BLAST) (Altschul et al. 1990).

Restriction length polymorphism: A PCR was performed with primers designed for amplification of Bonamia ostreae: Bo-Boas (Cochennec et al. 2000). Template DNA was obtained from Bonamia sp. infected Ostrea chilensis and B. ostreae infected $O$. edulis. The restriction fragment length polymorphism (RFLP) was studied by digesting $10 \mu \mathrm{l}$ of PCR product with Bgl1 (Promega). The pattern of resulting fragments was analysed electrophoretically on $2 \%$ agarose gel.

\section{RESULTS}

\section{Ultrastructural studies}

Four stages of Bonamia sp. development-dense, intermediate, plasmodial and vacuolated - were distinguished here, although forms intermediate to these were also observed. Quantitative data from electron micrographs of cells sectioned through the nucleus are given in Table 1.

Dense forms. In dense forms the nucleus was central and nearly circular in section, and the nucleolus was
Table 1. Bonamia ostreae and B. exitiosus (previously Bonamia sp.). Cytometric comparison of the dense forms based on sections through the middle of the cell. Haplosporosome measurements are based on 50 haplosporosomes from each species

\begin{tabular}{|c|c|c|}
\hline & B. ostreae & B. exitiosus \\
\hline Number examined & 64 & 61 \\
\hline Mean diameter $(\mu \mathrm{m})$ & $2.4 \pm 0.5$ & $3.0 \pm 0.3$ \\
\hline Mean no. mitochondria section ${ }^{-1}$ & $2 \pm 1$ & $3 \pm 1$ \\
\hline Mean no. haplosporosomes & $7 \pm 5$ & $14 \pm 6$ \\
\hline Mean haplosporosome diameter (nm) & $153 \pm 18$ & $148 \pm 11$ \\
\hline Range of haplosporosome diameters $(\mu \mathrm{m})$ & $127-187$ & 128-184 \\
\hline Sections with lipid droplets present (\%) & 7 & 49 \\
\hline Mean no. lipid droplets section ${ }^{-1}$ & $0.3 \pm 0.6$ & $0.8 \pm 0.9$ \\
\hline
\end{tabular}




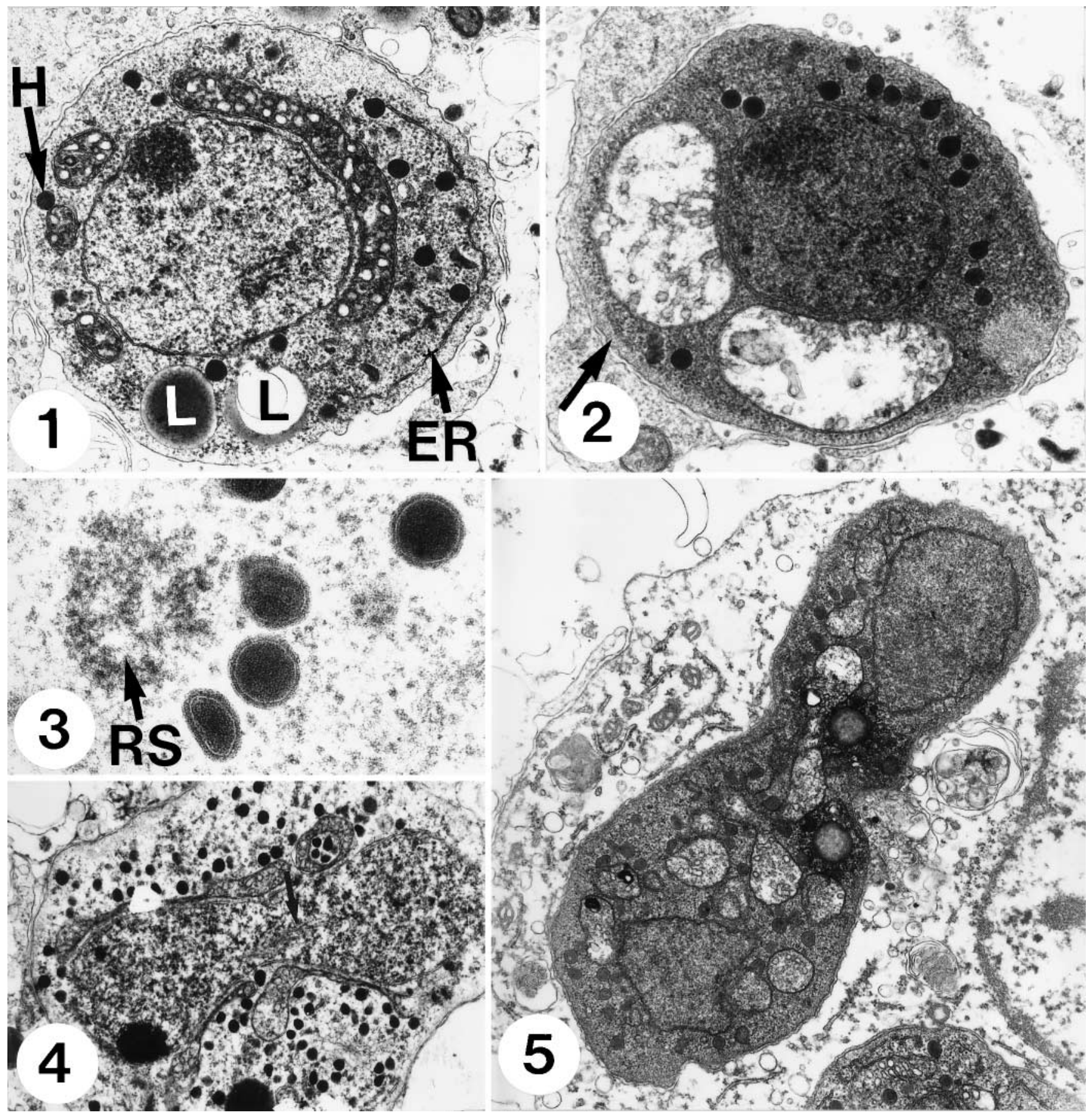

Figs 1 to 5. Bonamia sp. development, dense or early stages. Fig. 1. Dense form showing the central nucleus with eccentric nucleolus, mitochondrial sections around the nucleus, lipid bodies (L), haplosporosomes (H) and smooth endoplasmic reticulum (ER) $(\times 24200)$ Fig. 2. Dense form from the same section as Fig. 1. Note the 'blasted' appearance of the mitochondria, dense ribosomes and light cell margin (arrow) $(\times 24425)$. Fig. 3. Reticulated structure $(\mathrm{RS})$ and 4 haplosporosomes showing the characteristic internal membrane $(\times 96000)$. Fig. 4. Nucleus of dividing cell showing the dumb-bell shape and intranuclear microtubules (arrow) $(\times 14560)$. Fig. 5. Cell in which karyokinesis, but not cytokinesis, has occurred $(\times 21510)$

eccentric and often seen against the nuclear membrane (Figs 1 \& 2). Ribosomes occurred densely, except around the cell margin and underlying pseudopodia (Fig. 2). Sometimes curved strands of nuclear mem- brane-attached Golgi with thin dense deposits on the concave surface were observed, enclosing granular material at the nuclear surface. Intranuclear microtubules were present (Table 1), but were often 

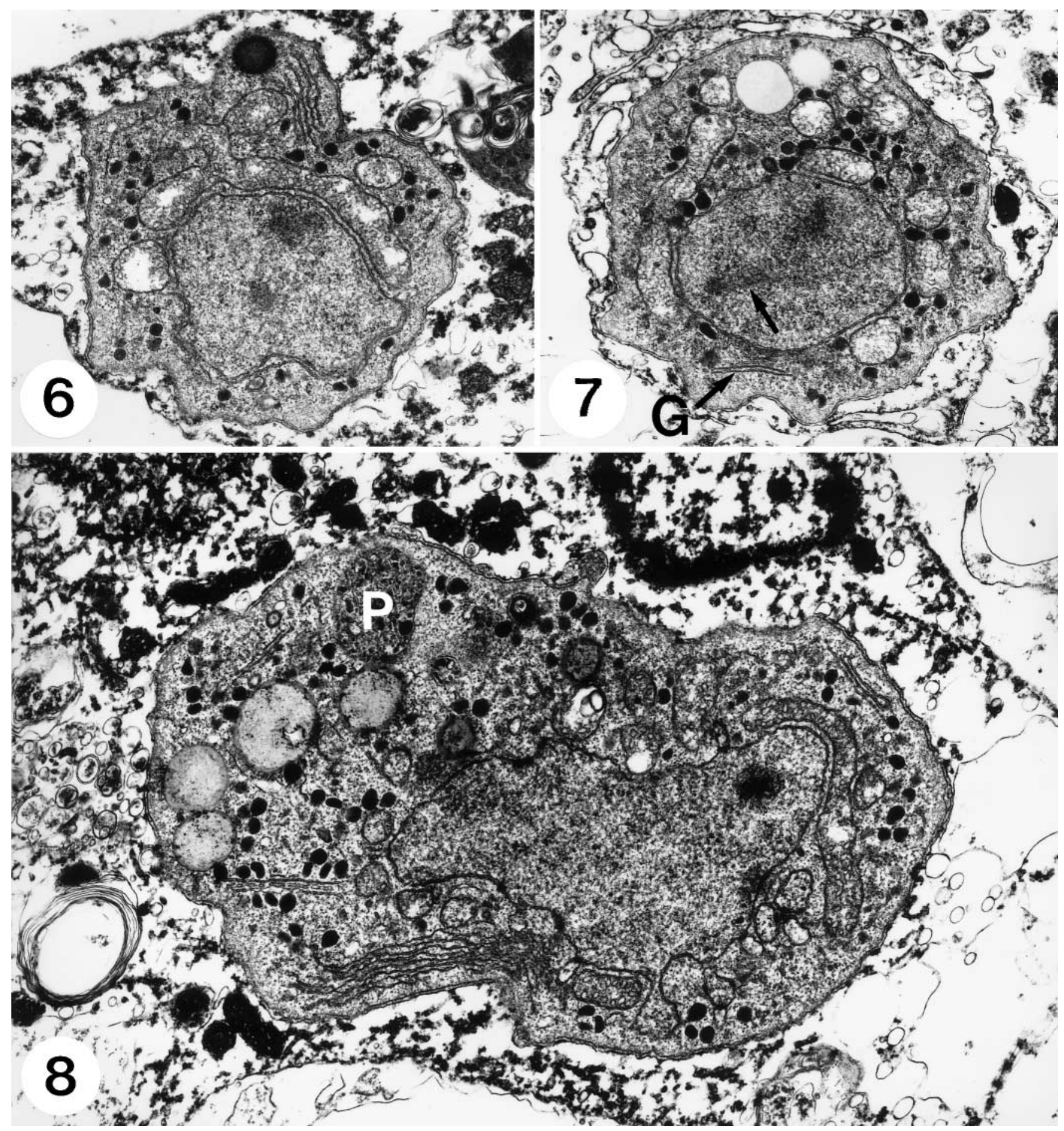

Figs 6 to 8. Intermediate and plasmodial forms. Fig. 6. Intermediate form showing the irregular nucleus and greater number of organelles, including peripheral smooth ER (sER) $(\times \overline{18610})$. Fig. 7. Intermediate form with intranuclear microtubules (arrow) and simple perinuclear Golgi $(G)(\times 18670)$. Fig. 8. Plasmodial form with an irregular nucleus, putative phagosomes (P) and large peripheral arrays of sER $(\times 21060)$

obscured by the dense nuclear contents.

Mitochondrial size and shape were variable, even in the same section (Figs $1 \& 2$ ), and they were often large and vacuous with sparse vesicular inclusions or mem- branous figures, or lacked contents. Mitochondrial sections were often wrapped around the nucleus (Fig. 1). Short strands of smooth endoplasmic reticulum (sER), $<3$ ovoid lipoid bodies lacking a limiting membrane 
and $<20$ haplosporosomes occurred among the ribosomes but not in the light cell margin (Fig. 2). A dense reticulated or vesicular structure occurred among the ribosomes near the boundary with the light margin (Fig. 3). Haplosporosomes were spherical, oval or pyriform, 128 to $184 \mathrm{~nm}$ in diameter $(\mathrm{n}=50)$ with a light internal membrane $3.5 \mathrm{~nm}$ wide (Fig. 3) that was rarely invaginated in section.

In dense and early intermediate forms division occurred by elongation of the nucleus (Fig. 4) followed by karyokinesis. This may occur rapidly as karyokinesis (Fig. 5) and the early stages of cytokinesis were seldom observed.

Intermediate forms. Intermediate forms were larger with less densely packed ribosomes, more mitochondrial profiles, lipoid bodies and haplosporosomes, and had an eccentric irregular nucleus with a central or eccentric nucleolus (Fig. 6) and intranuclear microtubules (Fig. 7). The clear cytoplasmic margin and reticulated structure were rarely observed. Mitochondria intermediate between dense and vacuous types predominated, but dense and vacuous mitochondria also occurred, sometimes in the same cell. Nuclear membrane-bound Golgi associated with material in cup-like indentations, detached Golgi and a few peripheral strands of sER were also present (Fig. 6).
Plasmodial forms. Plasmodial forms were larger cells with more irregular nuclear and cellular shape, Golgi/multi-vesicular body (MVB) complexes at which haplosporosomes formed and large peripheral arrays of sER (Fig. 8). Haplosporosomes, mitochondrial sections and lipoid bodies were more numerous than in intermediate and dense forms. Mitochondria were variable in appearance but usually dense and closely surrounding the nucleus, and were sometimes very attenuated. Endosomes containing pinocytosed or phagocytosed membranous inclusions were often present (Fig. 8). Nuclear membrane-bound Golgi/ granular material complexes, detached Golgi/granular material complexes and Golgi/MVB complexes occurred concurrently in individual plasmodia.

As well as the presence of Golgi/MVB complexes and large peripheral arrays of $\mathrm{sER}$, plasmodia were binucleate with the 2 nuclei forming a diplokaryon or were rarely tetranucleate. Diplokaryosis appeared to occur by infolding, on opposite sides of the cell, of the nuclear membrane covered with dense material (Fig. 9). Apposed faces, covered with dense material (Fig. 10), were joined at nuclear pores between which a very small internuclear chamber occasionally formed. Small strands of sER or Golgi cisternae were sometimes present between the 2 nuclei (Fig. 11).
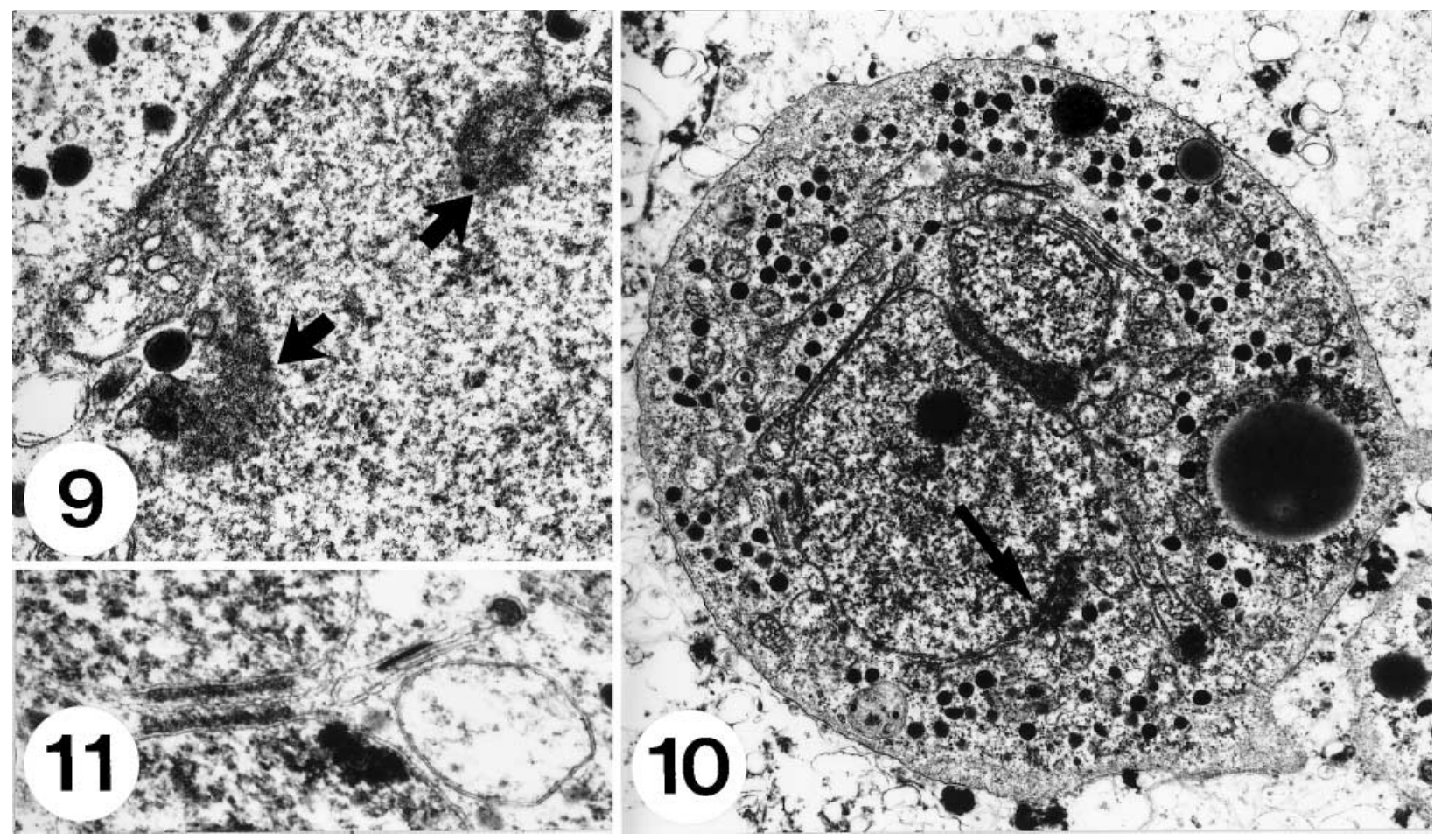

Figs 9 to 11. Diplokaryosis. Fig. 9. Inversion of the nuclear membrane at points where it is coated with dense material (arrows) $(\times 37500)$. Fig. 10. Diplokaryotic plasmodium showing the dense material between apposed nuclei, and at nuclear pores elsewhere on the nucleus (arrow) $(\times 13530)$. Fig. 11. Detail of dense material showing an intervening sER strand or single Golgi-like cisterna $(\times 30290)$ 


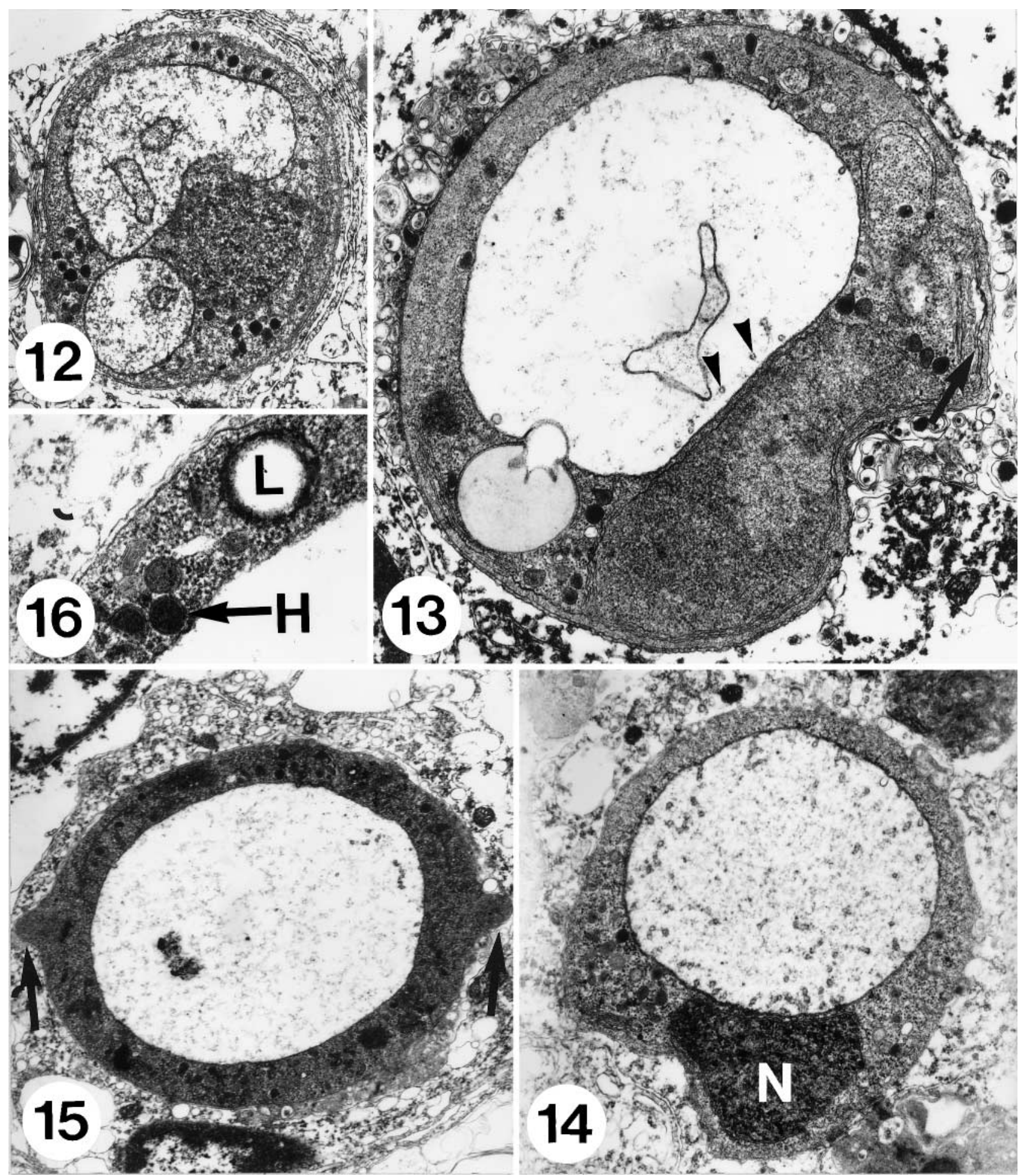

Figs 12 to 16. Vacuolated stages. Fig. 12. Gross enlargement of mitochondria containing sparse vesicular cristae $(\times 16070)$. Fig. 13. Presence of a single vacuole-like mitochondrion with a few cristae (arrowheads) and membranes that may derive from the lipid body. Perinuclear Golgi-like cisternae are present (arrow) $(\times 21760)$. Fig. 14. A similar stage as in Fig. 13 containing a dense, possibly degenerate nucleus $(\mathrm{N})(\times 17240)$. Fig. 15. Cell with a large central vacuole surrounded by dense cytoplasm, with a nipple-like protrusion from each end (arrows) $(\times 12360)$. Fig. 16. Detail of cytoplasm bordering the vacuole showing haplosporosomes $(\mathrm{H})$, remnant of a lipid body (L) and dense ribosomal content $(\times 42670)$. 
B. ostreae

B. sp.

B. ostreae

B. $\mathrm{sp}$

\begin{abstract}
\begin{tabular}{|c|c|}
\hline $\begin{array}{l}\text { B. ostreae } \\
\text { B. sp. }\end{array}$ & $\begin{array}{l}\text { CATTTAATTGGTCGGGCCGCTGGTCCTGATCCTTTACTTTGAGAAAATTAAAGTGCTCAA } \\
\text { CATTTAATTGGTCGGGCCGCTGGTCCTGATCCTTTACTTTGAGAAAATTAAAGTGCTCAA }\end{array}$ \\
\hline B. ostreae & AGCAGGCTCGCGCCTGAATGCATTAGCATGGAATAATAAGACACGACTTCGGCGCCGCC \\
\hline B. sp. & AGCAGGCTCGCGCCTGAATGCATTAGCATGGAATAATAAGACACGACTTCGGCGCCGCC \\
\hline B. ostreae & _GGCGGTTGTTTTGTTGGTTTTGAGCTGGAGTAATGATTGATAGAAACAATTGGG \\
\hline B. sp. & ACTCGTGGCGGGTGTTTTGTTGGTTTTGAGCTGGAGTAATGATTGATAGAAACAATTGGG \\
\hline B. ostreae & GGTGCTAGTATCGCCGGGCCAGAGGTAAAATTCTTTAATTCCGGTGAGACTAACTTATG \\
\hline B. sp. & GGTGCTAGTATCGCCGGGCCAGAGGTAAAATTCTTTAATTCCGGTGAGACTAACTTATG \\
\hline B. ostreae & CGAAAGCATTCACCAAGCGTGTTTTCTTTAATCAAGAACTAAAGTTGGGGGATCGAAGA \\
\hline B. sp. & CGAAAGCATTCACCAAGCGTGTTTTCTTTAATCAAGAACTAAAGTTGGGGGATCGAAGA \\
\hline B. ostreae & CGATCAG \\
\hline B. sp. & CGATCAG \\
\hline
\end{tabular}
CATTTAATTGGTCGGGCCGCTGGTCCTGATCCTTTACTTTGAGAAAATTAAAGTGCTCAA CATTTAATTGGTCGGGCCGCTGGTCCTGATCCTTTACTTTGAGAAAATTAAAGTGCTCAA

TC___GGGGTTGTTTTGTTGGTTTTGAGCTGGAGTAATGATTGATAGAAACAATTGGG ACTCGTGGCGGGTGTTTTGTTGGTTTTGAGCTGGAGTAATGATTGATAGAAACAATTGGG GGTGCTAGTATCGCCGGGCCAGAGGTAAAATTCTTTAATTCCGGTGAGACTAACTTATG CGAAAGCATTCACCAAGCGTGTTTTCTTTAATCAAGAACTAAAGTTGGGGGATCGAAGA CGATCAG
\end{abstract}

Vacuolated forms. Vacuolated cells (Figs 12 to 15) developed from cells with a poorly delineated nucleus, with cytoplasm around vacuous mitochondria (Fig. 12), one of which became very enlarged (Fig. 13) to form a central vacuole. The nucleus protruded slightly to give the cell section the appearance of a signet ring (Figs 13 $\& 14$ ), and Golgi-like cisternae were present near the apparently degenerating nucleus (Figs 13 \& 14). Mitochondrial vesicular cristae were present, although sparse (Figs 12, 13 \& 14). Membranous figures in the vacuole may be of mitochondrial origin (Fig. 12) or derive from lipid bodies (Fig. 13). Eventually the cell contained a large central vacuole bordered by a thin rim of cytoplasm, which had a nipple-like protrusion at each end (Fig. 15), giving the cell a bilateral symmetry. The cytoplasm was dense, ribosome-rich and contained haplosporosomes (Fig. 16), but a nucleus could not be distinguished.

Comparison with Bonamia ostreae. Dense forms of Bonamia ostreae were more dense, were smaller and had fewer haplosporosomes, mitochondrial profiles and lipoid bodies than Bonamia sp. (Table 1). The nuclear membrane was more osmiophilic and distinct in $B$. ostreae, and the tubulovesicular mitochondria were larger. B. ostreae dense forms lacked a clear cell margin, a dense reticulated structure near the margin, nuclear membrane-bound Golgi/nuclear cup complexes and a vacuolated stage.

\section{Base sequence studies}

Sequence. When PCR was applied to genomic DNA extracted from Bonamia sp. infected Ostrea chilensis using the universal primers SUni-CAS2, an amplicon of $1623 \mathrm{bp}$ was obtained. The GenBank Accession number is BankIt380719 AF337563. Comparisons of this sequence with public databases using BLAST confirmed that it belongs to SSU rDNA genes and is similar to the genus Haplosporidium. Alignment of the sequence from Bonamia sp. with the SSU rDNA genes of B. ostreae showed $96.6 \%$ homology.
Assessment of the SSU rDNA polymorphism. CLUSTALW multiple alignment programme showed a polymorphic region of 6 base pairs. This region was located inside the Bo-Boas primers amplified sequence (Fig. 17). Results of RFLP analysis of Bonamia ostreae and Bonamia sp. PCR products are given in Fig. 18. The B. ostreae profile consisted of 2 bands of 120 and $180 \mathrm{bp}$, respectively, while the Bonamia sp. profile consisted of a unique band of $304 \mathrm{bp}$.

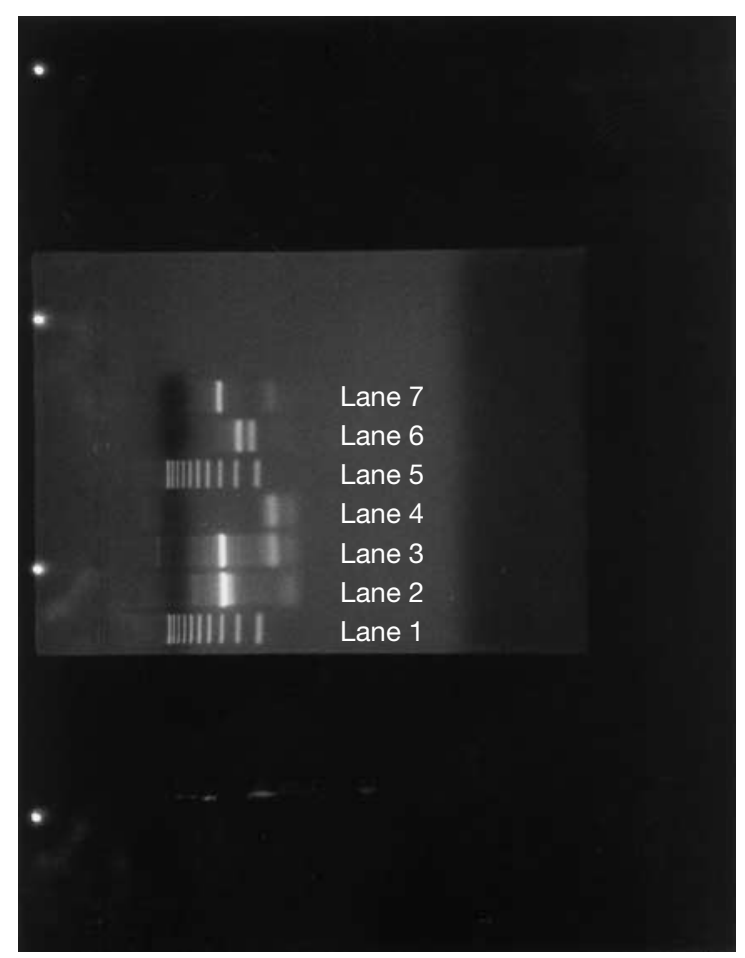

Fig. 18. $2 \%$ agarose gel electrophoresis. Lanes 1 and 5: $100 \mathrm{bp}$ molecular weight marker; Lanes 2 to 4 : PCR with primers BoBoas; Lane 2: DNA from Bonamia ostreae infected Ostrea edulis; Lane 3: DNA from Bonamia sp. infected O. chilensis; Lane 4: DNA from uninfected $O$. chilensis; Lanes 6 and 7: RFLP results; Lane 6: B. ostreae profile consists of 2 bands of 120 and $180 \mathrm{bp}$; Lane 7: Bonamia sp. profile consists of a unique band of $304 \mathrm{bp}$ 


\section{DISCUSSION}

\section{Ultrastructural studies}

The taxonomic position of Bonamia ostreae, Bonamia sp. (Hine 1991a,b, Hine \& Wesney 1994a,b), Mikrocytos spp. (Farley et al. 1988), and haplosporosome-bearing parasites of crabs (Newman et al. 1976) and shrimps (Dykovå et al. 1988) has been regarded as uncertain as they lack a known spore stage and, on this basis, Bonamia spp. were once excluded from the Haplosporidia (Perkins 1989).

Bonamia sp. resembles other haplosporidians in the persistence of intranuclear microtubules during interphase (Perkins 1975a,b, Marchand \& Sprague 1979) and the retention of the nuclear envelope during mitosis (Azevedo et al. 1985, Perkins 1988, 1989). The rounded dense cells are similar to the released sporoplasm of Minchinia dentale (Desportes \& Nashed 1983), although stages of sporulation and spores have never been observed in $B$. exitiosus infected oysters (Hine 1991b, Hine \& Wesney 1994a).

Plasmodia of Bonamia sp. are characterised by MVBs, and similar MVBs have been reported from plasmodia of Haplosporidium nelsoni and Urosporidium crescens (Perkins 1979). The diplokaryotic plasmodia of Bonamia sp. resemble other haplosporidians in the closely apposed nuclear surfaces (Perkins 1969, Marchand \& Sprague 1979, Bachère \& Grizel 1983, Desportes \& Nashed 1983, Azevedo et al. 1985, Bonami et al. 1985, Larsson 1987, Perkins 1989), the occurrence of dark material (Desportes \& Nashed 1983) and the small strands of sER (Perkins 1975a) between the nuclei.

The close apposition of the nuclear membrane and dense attenuated mitochondria in plasmodia of Bonamia sp. is similar to the bounding of nuclei by dense mitochondria in cysts of Haplosporidium comatulae (La Haye et al. 1984). Mitochondrial sections were also in close association with the nucleus in other stages from dense forms (Fig. 1) to more developed stages, and a similar association occurs in several other haplosporidians (Perkins 1969, Marchand \& Sprague 1979, Bachère \& Grizel 1983, La Haye et al. 1984). Variability of appearance of mitochondria has been attributed to fixation artefact (Perkins 1968, 1969, Rosenfield et al. 1969), but the occurrence of different forms in the same section (Figs $1 \& 2$ ) or the same cell cannot be attributed to fixation. As the mitochondria of the sporoplasm of Minchinia dentale change in size and density after release from the spore (Desportes \& Nashed 1983), mitochondrial appearance may indicate differences in metabolic state.

The vacuolated stage occasionally observed in Bonamia sp. is unlike any of the stages reported from other haplosporidians. The stage illustrated in Fig. 15 is bilaterally symmetrical and consequently resembles a spore. However, the bounding dense layer is cytoplasmic and lacks an external protective layer, and it is unlike the spore wall of other haplosporidians (Perkins 1979, 1989), such as Urosporidium (Anderson et al. 1993), Haplosporidium (Perkins 1968, 1969, La Haye et al. 1984, Azevedo et al. 1985, Hine \& Thorne 1998) and Minchinia (Marchand \& Sprague 1979, Desportes \& Nashed 1983, Comps \& Tigé 1997). Also, none of the early stages of haplosporidian sporulation, such as loss of haplosporosomes, thickening of the plasmodial wall and formation of a syncytium, have been reported from Bonamia sp. (Hine 1991b, 1992, Hine \& Wesney 1992, 1994a) or B. ostreae (Pichot et al. 1979, Comps et al. 1980, Brehélin et al. 1982, Bonami et al. 1985, Grizel 1985, Perkins 1988, 1989, Chagot et al. 1992).

\section{Comparison with Bonamia ostreae}

With the exception of the occasional mention of clear forms (Pichot et al. 1979, Grizel 1985), most of the information available in the literature on Bonamia ostreae concerns dense forms (Pichot et al. 1979, Comps et al. 1980, Brehélin et al. 1982, Balouet et al. 1983, Grizel et al. 1983, Grizel 1985, Montes et al. 1994) or stages slightly developed from it (Hervio et al. 1991, Chagot et al. 1992, Mourton et al. 1992). A Bonamia-like parasite that infected Suminoe oysters Crassostrea rivularis in France (Cochennec et al. 1998) appeared similar to $B$. ostreae and occurred as the dense form. B. ostreae dense forms resemble Bonamia sp. dense forms in the central circular nucleus, dense ribosomes, vacuous mitochondria, few haplosporosomes and clear margin. However, the dense form of $B$. ostreae is more dense, is smaller and has fewer haplosporosomes, mitochondrial profiles and lipoid bodies than Bonamia sp. (Table 1). As these features increase with development in Bonamia sp. (Table 2 in Hine 1991b), the lower number in $B$. ostreae may be due to the immaturity and smaller size of the stages observed. Size is unlikely to be due to the different host species, as experimental infection of Ostrea chilensis by $B$. ostreae still produces smaller dense forms than those observed here (Grizel et al. 1983).

The cup-like nuclear indentations with associated Golgi complexes and MVBs (Dinamani et al. 1987, Hine 1991b, 1992, Hine \& Wesney 1992), and the vacuolated stage (Hine 1991b) have not been reported from Bonamia ostreae. The reticulated structure (Hine \& Wesney 1992), which may be connected to anastomosing endoplasmic reticulum (Hine \& Wesney 1994a), and the Golgi associated with lipoid body genesis (Hine \& Wesney 1994a) have not been described in B. ostreae. However, the cylindrical confronting cister- 
nae in Bonamia sp. (Hine \& Wesney 1992) cannot be regarded as a difference between the species as they may be membranous abnormalities associated with parasite lipid metabolism and senescence (Hine \& Wesney 1994a).

Tetra-nucleate plasmodia were rare in this study, but multi-nucleated and diplokaryotic plasmodia appear more developed in Bonamia ostreae (Brehélin et al. 1982), particularly if the stages observed by Bonami et al. (1985) are those of B. ostreae. Also, B. ostreae differs from Bonamia sp. in its common occurrence in the stomach of the host (Balouet et al. 1983, Grizel 1985) and in producing macroscopic gill lesions in Ostrea edulis (Tigé et al. 1980, Grizel 1985) and O. chilensis (Grizel et al. 1983).

Overall, the dense form of Bonamia exitiosus resembles the sporoplasm of some haplosporidians and develops into a typical haplosporidian diplokaryotic plasmodial stage. The vacuolated stage is unlike any reported so far from other haplosporidians, but the characteristic haplosporosomes clearly show this is a developmental stage of a haplosporidian. In the appearance of early developmental dense forms (Hine 1991b) and lack of spore stages, Bonamia sp. most closely resembles $B$. ostreae.

These results point out that haplosporidian phylogenetic considerations based only on ultrastructural features description are not sufficient to elucidate taxonomy. Ultrastructural studies are essential as a first step towards elucidation of the taxonomic boundaries but should be supported by genetic information. The SSU rDNA gene of Bonamia sp. was sequenced because this gene has been widely used in the taxonomic study of similar organisms including B. ostreae and Haplosporidium spp. The SSU rDNA sequence of $B$. ostreae showed strong similarities with Haplosporidium nelsoni, $H$. costale and Minchinia teredinis (Cochennec et al. 2000). Similarly, B. ostreae has been placed between $H$. nelsoni and $H$. costale in another molecular study (Carnegie et al. 2000). These data suggest that $B$. ostreae may eventually be included in the genus Haplosporidium. However, phenotypic characters also have to be taken into account, and the lack of a known spore stage in Bonamia spp. and the difference of the vacuolated stage to any known stage in Haplosporidium spp. would make it premature to place Bonamia spp. in the genus Haplosporidium. The SSU rDNA sequence of Bonamia sp. had strong identity with those of $B$. ostreae, but some divergent regions were evident. This polymorphism within Bonamia species was confirmed by RFLP analysis. These results suggest that these 2 parasites are congeneric.

For that reason we propose the specific species name exitiosus for Bonamia sp. 'Exitiosus' is Latin for 'destructive', and describes the pathogenicity of this parasite. Also, 'exit' in English means 'departure of player from stage' (Concise Oxford Dictionary), and 'tio' is Maori for the host oyster species.

Acknowledgements. We are grateful to the late Dominique Chagot of La Tremblade laboratory for loaning negatives and to Dr Steve Feist of the CEFAS laboratory, Weymouth, England, for lending blocks for TEM study. We are also grateful to CEE for financial support.

\section{LITERATURE CITED}

Altschul SF, Gish W, Miller W, Myers EW, Lipman DJ (1990) Basic local alignment search tool. J Mol Biol 215:403-410

Anderson TJ, Newman LJ, Lester RJG (1993) Light and electron microscope study of Urosporidium cannoni n. sp. haplosporidian parasite of the polyclad turbellarian Stylochus sp. J Eukaryot Microbiol 40:162-168

Azevedo C, Corral L, Perkins FO (1985) Ultrastructural observations of spore excystment, plasmodial development and sporoblast formation in Haplosporidium lusitanicum (Haplosporida, Haplosporidiidae). Z Parasitenkd 71:715-726

Bachère E, Grizel H (1983) Mise en evidence d'Haplosporidium sp. (Haplosporida - Haplosporidiidae) parasite de l'huître plate Ostrea edulis L. Rev Trav Inst Pêches Marit 46:226-232

Balouet G, Poder M, Cahour A (1983) Haemocytic parasitosis: morphology and pathology of lesions in the French flat oyster, Ostrea edulis L. Aquaculture 34:1-14

Bonami JR, Vivarès CP, Brehélin M (1985) Étude d'une nouvelle Haplosporidie parasite de l'huître plate Ostrea edulis L.: morphologie et cytologie de différents stades. Protistologica 21:161-173

Brehélin M, Bonami JR, Cousserans F, Vivarès CP (1982) Existence de formes plasmodiales vraies chez Bonamia ostreae parasite de l'huître plate Ostrea edulis. C R Acad Sci Paris Série III 295:45-48

Carnegie RB, Barber BJ, Culloty, SC, Figueras AJ, Distel, DL (2000). Development of a PCR assay for detection of the oyster pathogen Bonamia ostreae and support for its inclusion in the Haplosporidia. Dis Aquat Org 42:199-206

Chagot D, Boulo V, Hervio D, Mialhe E, Mourton C, Grizel H (1992) Interactions between Bonamia ostreae (Protozoa: Ascetospora) and hemocytes of Ostrea edulis and Crassostrea gigas (Mollusca: Bivalvia): entry mechanisms. J Invertebr Pathol 59:241-249

Cochennec N, Renault T, Boudry P, Chollet B, Gerard A (1998) Bonamia-like parasite found in the Suminoe oyster Crassostrea rivularis reared in France. Dis Aquat Org 34: 193-197

Cochennec N, Le Roux F, Berthe F (2000) Detection of Bonamia ostreae based on small subunit ribosomal probe. J Invertebr Pathol 76:26-32

Comps M, Tigé G (1997) Fine structure of Minchinia sp., a haplosporidan infecting the mussel Mytilus galloprovincialis. Syst Parasitol 38:45-50

Comps M, Tigé G, Grizel H (1980) Étude ultrastructurale d'un Protiste parasite de l'huitre Ostrea edulis. C R Acad Sci Paris Série III 290:383-384

Desportes I, Nashed NN (1983) Ultrastructure of sporulation in Minchinia dentale (Arvy), an haplosporean parasite of Dentalium entale (Scaphopoda, Mollusca); taxonomic implications. Protistologica 19:435-460 
Dinamani P, Hine PM, Jones JB (1987) Occurrence and characteristics of the haemocyte parasite Bonamia sp. in the New Zealand dredge oyster Tiostrea lutaria. Dis Aquat Org 3:37-44

Doonan IJ, Cranfield HJ, Michael K (1994) Catastrophic reduction of the oyster, Tiostrea chilensis (Bivalvia: Ostreidae), in Foveaux Strait, New Zealand, due to infestation by the protistan Bonamia sp. NZ J Mar Freshwat Res 28: 335-344

Dykovå I, Lom J, Fajer E (1988) A new haplosporean infecting the hepatopancreas in the penaeid shrimp, Penaeus vannemai. J Fish Dis 11:15-22

Farley CA, Wolf PH, Elston RA (1988) A long-term study of 'microcell' disease in oysters with a description of a new genus, Mikrocytos (g.n.), and two new species, Mikrocytos mackini (sp.n.) and Mikrocytos roughleyi (sp.n.). Fish Bull 86:581-593

Grizel H (1985) Étude des récentes épizooties de l'huîtres plate Ostrea edulis L. et de leur impact sur l'ostreiculture Bretonne. Thèse de Doctorat. Université des Sciences Techniques du Languedoc, Montpellier

Grizel H, Comps M, Raguenes D, Leborgne Y, Tigé G, Martin AG (1983) Bilan des essais d'acclimatation d'Ostrea chilensis sur les côtes de Bretagne. Rev Trav Inst Pêches Marit 46:209-225

Hervio D, Chagot D, Godin P, Grizel H, Mialhe E (1991) Localization and characterization of acid phosphatase activity in Bonamia ostreae (Ascetospora), an intrahemocytic protozoan parasite of the flat oyster Ostrea edulis. Dis Aquat Org 12:67-70

Hine PM (1991a) The annual pattern of infection by Bonamia sp. in New Zealand flat oysters, Tiostrea chilensis. Aquaculture 93:241-252

Hine PM (1991b) Ultrastructural observations on the annual infection pattern of Bonamia sp. in flat oysters Tiostrea chilensis. Dis Aquat Org 11:163-171

Hine PM (1992) Ultrastructural and ultracytochemical observations on Bonamia sp. in oysters (Tiostrea chilensis), with a consideration of organelle function. Aquaculture 107: 175-183

Hine PM (1996) The ecology of Bonamia and decline of bivalve molluscs. NZ J Ecol 20:109-116

Hine PM, Jones JB (1994) Bonamia and other aquatic parasites of importance to New Zealand. NZ J Zool 21:49-56

Hine PM, Thorne T (1998) Haplosporidium sp. (Haplosporidia) in hatchery-reared pearl oysters, Pinctada maxima (Jameson, 1901), in north Western Australia. J Invertebr Pathol 71:48-52

Hine PM, Wesney B (1992) Inter-relationships of cytoplasmic structures in Bonamia sp. (Haplosporidia) infecting oysters Tiostrea chilensis: an interpretation. Dis Aquat Org 14: 59-68

Hine PM, Wesney B (1994a) The functional cytology of Bonamia sp. (Haplosporidia) infecting oysters Tiostrea chilensis: an ultracytochemical study. Dis Aquat Org 20:207-217

Hine PM, Wesney B (1994b) Interaction of phagocytosed Bonamia sp. (Haplosporidia) with haemocytes of oysters Tiostrea chilensis. Dis Aquat Org 20:219-229

La Haye CA, Holland ND, McLean N (1984) Electron microscopic study of Haplosporidium comatulae n. sp. (Phylum Ascetospora: Class Stellatosporea), a haplosporidian endoparasite of an Australian crinoid, Oligometra serripinna (Phylum Echinodermata). Protistologica 20:507-515
Larsson JIR (1987) On Haplosporidium gammari, a parasite of the amphipod Rivulogammarus pulex, and its relationships with the phylum Ascetospora. J Invertebr Pathol 49: 159-169

Le Roux F, Audemard C, Barnaud A, Berthe F (1999) DNA probes as potential tools for the detection of Marteilia refringens. Mar Biotechnol 1:588-597

Marchand J, Sprague V (1979) Ultrastructure de Minchinia cadomensis sp.n. (Haplosporida) parasite du décapode Rhithropanopeus harrisii tridentatus Maitland dans le canal de Caen à la mer. J Protozool 26:179-185

Mialhe E, Boulo V, Elston R, Hill B, Hine M, Montes J, van Banning P, Grizel H (1988) Serological analysis of Bonamia in Ostrea edulis and Tiostrea lutaria using polyclonal and monoclonal antibodies. Aquat Living Resour 1: 67-69

Montes J, Anadon R, Azevedo C (1994) A possible life cycle for Bonamia ostreae on the basis of electron microscopy. J Invertebr Pathol 63:1-6

Mourton C, Boulo V, Chagot D, Hervio D, Mialhe E, Grizel H (1992) Interactions between Bonamia ostreae (Protozoa: Ascetospora) and hemocytes of Ostrea edulis and Crassostrea gigas (Mollusca: Bivalvia): in vitro system establishment. J Invertebr Pathol 59:235-240

Newman MW, Johnson CA, Pauley GB (1976) A Minchinialike haplosporidan parasitizing blue crabs, Callinectes sapidus. J Invertebr Pathol 27:311-315

Perkins FO (1968) Fine structure of the oyster pathogen Minchinia nelsoni (Haplosporida, Haplosporidiidae). J Invertebr Pathol 10:287-307

Perkins FO (1969) Electron microscope studies of sporulation in the oyster pathogen, Minchinia costalis (Sporozoa: Haplosporida). J Parasitol 55:897-920

Perkins FO (1975a) Fine structure of Minchinia sp. (Haplosporida) sporulation in the mud crab, Panopeus herbstii. Mar Fish Rev 37:46-60

Perkins FO (1975b) Fine structure of the haplosporidan KERNSTAB, a persistent, intranuclear mitotic apparatus. J Cell Sci 18:327-346

Perkins FO (1979) Cell structure of shellfish pathogens and hyperparasites in the genera Minchinia, Urosporidium, Haplosporidium, and Marteilia: taxonomic implications. Mar Fish Rev 41:25-37

Perkins FO (1988) Structure of protistan parasites found in bivalve molluscs. In: Fisher WS (ed) Disease processes in marine bivalve molluscs. Am Fish Soc Spec Publ 18: 93-111

Perkins FO (1989) Phylum Haplosporidia. In: Margulis L, Corliss JO, Melkonian M, Chapman DJ (eds) Handbook of protoctista. Jones and Bartlett, Boston, p 19-29

Pichot Y, Comps M, Tigé G, Grizel H, Rabouin MA (1979) Recherches sur Bonamia ostreae gen. n., sp. n., parasite nouveau de l'huître plate Ostrea edulis L. Rev Trav Inst Pêches Marit 43:131-140

Rosenfield A, Buchanan L, Chapman GB (1969) Comparison of the fine structure of spores of three species of Minchinia (Haplosporida, Haplosporidiidae). J Parasitol 55:921-941

Sambrook J, Fritsch EF, Maniatis T (1989) Molecular cloning: a laboratory manual. Cold Spring Harbor Laboratory, Cold Spring Harbor, NY

Tigé G, Grizel H, Comps M (1980) Données sur le nouveau parasite de l'huître plate. Situation épidémiologique. Cons Int Explor Mer CM 1980/F:39, Copenhagen

Submitted: January 18, 2001; Accepted: May 15, 2001

Proofs received from author(s): September 25, 2001 